\title{
Effects of Astaxanthin on The Skin Color of Green Swordtail, Xyphophorus helleri
}

\author{
Dedi F. Putra ${ }^{1 *}$, Ahmad Qadri $^{1}$, Sayyid A. El-Rahimi ${ }^{1}$, and Norhayati Othman ${ }^{2}$ \\ ${ }^{1}$ Department of Aquaculture, Faculty of Marine and Fisheries, Universitas Syiah Kuala, Banda Aceh 23111, Indonesia \\ ${ }^{2}$ Cluster of Applied Sciences, Open University Malaysia, Penang 13700 Malaysia
}

\begin{abstract}
This study aimed to analyze the effects of astaxanthin in commercial feed on growth and color intensity of green swordtail fish, Xyphophorus helleri. A total of 150 green swordtail fish (Xyphophorus helleri) had an average weight of $\pm 2 \mathrm{~g}$ per fish was used. A Completely Randomized Design (CRD) was used consisting of five treatments and three replicates. The treatments were A $(0 \mathrm{mg} / \mathrm{kg}), \mathrm{B}(50 \mathrm{mg} / \mathrm{kg}), \mathrm{C}(100$ $\mathrm{mg} / \mathrm{kg}), \mathrm{D}(150 \mathrm{mg} / \mathrm{kg}), \mathrm{E}(200 \mathrm{mg} / \mathrm{kg})$. Observation of color intensity had done once every 10 days for four weeks using TCF (Toca Color Finder). The result showed that the addition of astaxanthin into commercial feeds with different doses has a significant effect on the skin color intensity of green swordtail fish (Xyphophorus helleri). Hence, the concentration of $200 \mathrm{mg} / \mathrm{kg}$ Astaxanthin had the optimum skin color intensity of green swordtail fish (Xyphophorus helleri).
\end{abstract}

Keywords: Astaxanthin, skin color, Xyphophorus helleri.

\section{Introduction}

The green swordtail fish, Xyphophorus helleri is one of the popular ornamental fish that belong to the top 4 of popular aquarium freshwater fish in the world [1]. It has a green sword-like tail shape and a red body color that make the good-looking uniqueness. Its body color will determine the market value and the level of consumer demand. The brighter is the color of a type of fish, the higher the value is [2]. Therefore, the color must be improved to increase its quality. One of the efforts made to obtain bright and even colors in fish is by manipulation of pigment techniques, by enriching the content of pigment cells in the fish's body through feeding containing astaxanthin (Carophyll pink) [3].

Beautiful colors in fish occur because of the number and location of pigment cells (chromatophores) in the epidermal layer of fish [4]. Pigment cells can be classified into 5 basic color categories, namely black (melanophore), yellow (xanthofor), red or orange (erythrofor), sheen reflection cells (iridofor), and white (leukofor) [5]. Other studies also support that chromatophores are pigment cells that are round and spread throughout the epidermal skin layers of fish [6].

The main component of color pigment forming is carotenoid which is a component of natural pigment that contributes quite well to the red and orange colors [7]. In general, fish will absorb astaxanthin from feed and use it directly as a red pigment cell. Astaxanthin is commonly added to feed to prevent the absence of color pigments in aquaculture [8].

Fish that live in nature get carotenoids from the feed in the form of phytoplankton or zooplankton that consume algae and photosynthetic bacteria. Maintenance of ornamental fish intensively in clear water or aquarium causes the fish lack of live feed, therefore the carotenoids containing pellet must be given [9].

Astaxanthin is a carotenoid that can be found in freshwater and the largest concentration can be found in green algae (Haematoccocus pluvialis), which is 10.000 $40.000 \mathrm{mg} / \mathrm{kg}$. Comparative studies between astaxanthin and other types of carotene have shown that astaxanthin has antioxidant activity 10 times stronger than the carotene group in the form of beta-carotene, cantaxanthin, lutein, zeaxanthin [10]. However, there is almost no research about the effect of Astaxanthin on Xyphophorus helleri has been done. Therefore, in this study, we investigated the effect of Astaxanthin on the skin color of Xyphophorus helleri.

\section{Materials and Methods}

\subsection{Experimental Design}

This research was conducted for 30 days from March to April 2018, located at the Laboratory of Marine Biology, Faculty of Marine and Fisheries, Syiah Kuala University. A completely randomized design (CRD) with 5 treatments and 3 replications was used. The treatments were:

Treatment A: No Astaxanthin powder (Control) Treatment B: Astaxanthin powder $50 \mathrm{mg} / \mathrm{kg}$ of feed Treatment C: Astaxanthin powder $100 \mathrm{mg} / \mathrm{kg}$ of feed Treatment D: Astaxanthin powder $150 \mathrm{mg} / \mathrm{kg}$ of feed Treatment E: Astaxanthin powder $200 \mathrm{mg} / \mathrm{kg}$ of feed

* Corresponding author: dfputra@unsyiah.ac.id 
A $\pm 4 \mathrm{~cm}$ length of Xyphophorus helleri obtained from ornamental fish in Banda Aceh. The fish were placed in the container to be acclimatized for 30 minutes.

The commercial feed pellet mixed with astaxanthin powder at four different dosages. The pellet mixed with 2-3 $\mathrm{g}$ of adhesive/ $\mathrm{kg}$ of feed and astaxanthin flour with the appropriate dosage of treatment. Then the mixture was mixed with $150 \mathrm{ml} / \mathrm{kg}$ of water and stirred until being homogeneous. Furthermore, the solution was mixed with feed, stirred evenly and dried.

\subsection{Research Parameters}

\subsubsection{Color Observation}

The color observation method was mentioned previously [2]. Color measurements were carried out using a color measuring tool, the Toca Color Finder (TCF) by means of observation, which is focused on two colors that are close to the body color of the test fish. The measurement of the color of the test fish was observed by 5 panelists who did not have visual impairments (color blindness and farsightedness). Observations were made visually by comparing the original colors of fish on a color measuring paper that had been given a weighting. Observation of the skin color change of Xyphophorus helleri was done by grading or weighting on a color measuring paper. Ratings started from the smallest $1,2,3$ to the largest score of 8 with gradations of colors from light orange to dark red. Color observations are carried out once every 10 days for 30 days.

\subsubsection{Water quality}

The water quality was controlled in such a way as to be in accordance with the optimum water quality of the growth of the Xyphophorus helleri. The siphoning process was carried out once every 10 days by $10 \%$ and water replacement was carried out after the process of measuring water quality every 7 days. Measurement of water quality in the form of $\mathrm{DO}, \mathrm{pH}$, and temperature was done every 7 days before the process of water replacement.

\subsubsection{Absolute Growth}

The growth parameter tested was [11]:
$\mathrm{Wm}=\mathrm{Wt}-\mathrm{Wo}$

Note:

$\mathrm{Wm}=$ Weight (growth of absolute weight of fish) $(\mathrm{g})$

$\mathrm{Wt}=$ Weight (weight of the fish at $\mathrm{t}$-time) $(\mathrm{g})$

$\mathrm{W} 0=$ Weight (initial weight $)(\mathrm{g})$.

\subsubsection{Absolute Length}

$\mathrm{Pm}=\mathrm{Pt}-\mathrm{P} 0[11]$

Note:

$\mathrm{Pm}=$ Increase in absolute length of fish $(\mathrm{cm})$

$\mathrm{Pt}=$ length of Fish at $\mathrm{t}$-time $(\mathrm{cm})$

$\mathrm{P} 0=$ length of fish at time $0(\mathrm{~cm})$

\subsubsection{Survival rate}

The survival of the tested fish calculated using the formula [12]:

$\mathrm{SR}=(\mathrm{N} 0-\mathrm{Nt}) / \mathrm{N} 0 \times 100 \%$

Note:

$\mathrm{SR}=$ Survival rate (survival rate of test fish) $(\%)$

$\mathrm{Nt}=$ Number (number of test fish that live at the t-time) (tail)

NO $=$ Number (number of test fish that lived early in the study) (tail).

\subsection{Data analysis}

The data were analyzed using Analysis of Variance Analysis (one way ANOVA).

\section{Results and Discussion}

ANOVA test results showed that the administration of astaxanthin powder in Xyphophorus helleri pellets with different concentrations had a significant effect on the color change ( $\mathrm{P}<0.05)$. Duncan's further test showed the best color change in treatment $\mathrm{E}$ (200 $\mathrm{mg}$ dose) and the lowest in treatment A (control), but it did not significantly affect the growth of absolute weight, absolute length, and survival $(\mathrm{P}>0.05)$.

Table 1. Skin Color observation, absolute weight growth, absolute length, and survival rate of Xyphophorus helleri.

\begin{tabular}{lllll}
\hline \multirow{2}{*}{ Treatment } & \multicolumn{3}{l}{ Research Parameters } & \\
\cline { 2 - 5 } & $\begin{array}{l}\text { Skin Color } \\
\text { Observation }\end{array}$ & Absolute growth (gram) & Absolute length $(\mathrm{cm})$ & $\begin{array}{l}\text { Survival rate } \\
(\%)\end{array}$ \\
\hline A (Control) & $1,40 \pm 0,34^{\mathrm{a}}$ & $1,00 \pm 1,06^{\mathrm{a}}$ & $1,74 \pm 0,04^{\mathrm{a}}$ & $80 \pm 10^{\mathrm{a}}$ \\
B (50 mg) & $2,46 \pm 0,50^{\mathrm{b}}$ & $0,95 \pm 0,00^{\mathrm{a}}$ & $1,90 \pm 0,43^{\mathrm{a}}$ & $70 \pm 10^{\mathrm{a}}$ \\
C (100 mg) & $2,60 \pm 0,00^{\mathrm{b}}$ & $0,98 \pm 0,05^{\mathrm{a}}$ & $1,49 \pm 0,18^{\mathrm{a}}$ & $83 \pm 5,7^{\mathrm{a}}$ \\
D (150 mg) & $3,33 \pm 0,23^{\mathrm{c}}$ & $1,09 \pm 0,09^{\mathrm{a}}$ & $2,02 \pm 0,74^{\mathrm{a}}$ & $80 \pm 10^{\mathrm{a}}$ \\
E (200 mg) & $4,20 \pm 0,20^{\mathrm{d}}$ & $1,06 \pm 0,14^{\mathrm{a}}$ & $1,67 \pm 0,25^{\mathrm{a}}$ & $86 \pm 5,7^{\mathrm{a}}$ \\
\hline
\end{tabular}

Note: Different superscripts in the column show a significant difference $(\mathrm{P}<0.05)$

The results showed that the change in color of Xyphophorus helleri for 30 days has increased every week with varying values. The increase in color in the fish was due to the influence of different astaxanthin flour powder and the digestibility of Xyphophorus helleri to the carotene content in the experimental feed. According to [13], the increase of fish skin color occurs varies according to the absorption of fish against the type of 
pigment and the dose given at each treatment. The research showed that the addition of $200 \mathrm{mg}$ of astaxanthin flour was the best and effective treatment to improve the color of Xyphophorus helleri (Table 1).

Referring to [14], fish physiologically need more time to break down carotene material into color pigments.. if pigments in the feed are in excessive amounts; it will even decrease the color value of fish. The highest and most effective color change in the body was found in treatment E (dose $200 \mathrm{mg}$ ). On day 14 the color of Xyphophorus helleri started to improve become brighter. The increase in the color of Xyphophorus helleri occurred on the 21st day. Meanwhile, [2] stated that the administration of carotenoids in feed for 2 weeks stimulated the increasing of goldfish color. Meanwhile, other study reported that the coloration of marine ornamental fish was formed at post juvenile stage [15]. It is obvious that the coloration of ornamental fish is closely related to fish development stage.

Chromatophores are cells that play a role in increasing or decreasing the brightness of fish. If the number of chromatophores cells increases, the higher the brightness of the fish and vice versa [16]. Treatment A as a control still showed color changes, but not it was not better than feed with astaxanthin powder. This was presumably because the feed contains pigment color from the feed ingredients, namely fish meal, so it indirectly affects the slight discoloration of fish [17].

The previous studies reported that [13] various sources of natural beta carotene is used to improve the brightness of koi fish (Cyprinus carpio). The studies showed that the biggest fish skin color change was in the treatment of astaxanthin powder at $3 \%$ with a value of 0.97 , then 0.71 for the Spirulina powder and 0.68 for carrot powder. Every fish does not have the same way to absorb carotenoids and therefore there is no similar change in the body tissue of every fish [18].

The absolute weight growth, absolute length growth, and survival rate did not show a significant effect on Xyphophorus helleri ( $\mathrm{P}>0.05)$. A similar result was reported from another study [2-3, 19].

Table 2. Water quality parameters.

\begin{tabular}{|c|c|c|c|}
\hline \multirow[t]{2}{*}{ Treatment } & \multicolumn{2}{|c|}{ Water Quality Parameters } & \multirow[b]{2}{*}{$\mathrm{DO}(\mathrm{mg} / \mathrm{L})$} \\
\hline & Temperature $\left({ }^{\circ} \mathrm{C}\right)$ & $\mathrm{pH}$ & \\
\hline A & 27 & 7 & 2,97 \\
\hline B & 28 & 7 & 2,97 \\
\hline $\mathrm{C}$ & 27 & 7 & 3,13 \\
\hline $\mathrm{D}$ & 27 & 7 & 2,97 \\
\hline $\mathrm{E}$ & 27 & 7 & 2,97 \\
\hline \multirow{2}{*}{ Optimal } & $25-27$ & $7-8$ & 3,0 \\
\hline & (Tamaru et al., 2001)[1] & & \\
\hline
\end{tabular}

The temperature obtained in the maintenance media was around $27{ }^{\circ} \mathrm{C}$ and was still in the optimal range [11]. According to table 2, the optimal acidity $(\mathrm{pH})$ of water for Xyphophorus helleri was ranged from 7.0 to 8.0. The degree of acidity $(\mathrm{pH})$ during the study was 7.0. The content of dissolved oxygen (DO) during the study ranged from 2.97 to $3.13 \mathrm{mg} / \mathrm{L}$. The water quality measurement result was still intolerance level for Xyphophorus helleri [1]. According to [20], the optimal temperature for Xyphophorus helleri is around $25{ }^{\circ} \mathrm{C}-27{ }^{\circ} \mathrm{C}$. Thus the quality of water during fish maintenance must be maintained according to the optimal value of the water quality of the Xyphophorus helleri.

\section{Conclusion}

The dietary administration of Astaxanthin powder at different concentrations in feed significantly affected the color improvement but did not significantly affect the absolute weight gain, absolute length and survival rate of Xyphophorus helleri. The optimum concentration of Astaxanthin powder was $200 \mathrm{mg}$ (treatment E).

\section{References}

1. Tamaru CS, Cole B, Bailey R, et al. : A manual for commercial production of the swordtail, Xiphophorus helleri. CTSA Publication. 2001; 36p.
2. Putra DF, Armaya L, Rahimi SAE, et al. : Effects of red yam flour (Ipomoea batatas l.) on the growth, survival rate and skin color of goldfish (Carrasius auratus). BIOTROPIA. 2019;26(2):136-142

3. Sitorus AMG, Usman S, Nurmatias: The effect of astaxanthin concentration on feed on the increase in the color of goldfish (Carassius auratus). Journal of Aquacoastmarine. 2015; 8 (3): 10. [Indonesian]

4. Sari, NP, Santoso L., Hudaidah S: . Effect of addition of shrimp head flour in feed on pigmentation of koi (Cyprinus carpio) kohaku family. e-Jurnal Rekayasa dan Teknologi Budidaya Perairan. 2012; 1(1): 32-38. [Indonesian]

5. Sally E: Pigment Granula Transport in Cromatophores. Department of Biology Bucknell University, Lewisburg.143-157. 1997.

6. Indarti S, Muhaemin M, Hudaidah S: Modified Toca Color Finder (MTCF) and chromatophores as predictors of the color brightness of comet fish (Carassius auratus) fed with different proportions of shrimp head flour. Jurnal Rekayasa dan Teknologi Budidaya Perairan. 2012; 1(1): 10-16. [Indonesian]

7. Sulawesty F: Improved appearance of male red rainbow fish (Glossolepsis insicus) by using total carotenoids from rebon. LIMNOTEK Perairan Darat Tropis di Indonesia. Puslitbang Limnologi LIPI. 1997. [Indonesian]

8. Cejas J, Almansa E, Tejera N, et al. : Effect of dietary supplementation with shrimp on skin pigmentation and lipid composition of red porgy (Pagrus pagrus) alevins. Aquaculture. 2003; 218: 457-469. 
9. Gouveia L, Rema P, Pereira O, et al. : J Coloring ornamental fish (Cyprinus carpio and Carassius auratus) with micro-algae biomass. Aquaculture Nutrition 2003;9:123-129.

10. Naguib YMA: Antioxidant activities of astaxanthin and related carotenoids. Journal of Agricultural Chemicals. 2000; 48: 1150-1154.

11. Effendie: Fishery biology methods. Dwisri, Bogor. 112p. 1979. [Indonesian]

12. Zonneveld N, Huisman EA, Boon JH: Fish farming. Gramedia: Jakarta. 1991. [Indonesian]

13. Hulu EA, Usman S, Nurmatias N: Addition of various sources of natural beta carotene in feed to increase the brightness of the color of Koi fish (Cyprinus carpio). Journal Aquacoastmarine. 2015; 10 (5): 62-71. [Indonesian]

14. Barus RS, Usman S, Nurmatias N: The effect of spirulina platensis flour concentration on feed on the increase in the color of goldfish (Carassius auratus). Journal Aquacoastmarine. 2014; 5(4): 82-92. [Indonesian]

15. Putra DF, Abol-munafi AB, Muchlisin ZA, et al. : Preliminary studies on morphology and digestive tract development of tomato clownfish, Amphiprion frenatus under captive condition. Aquaculture, Aquarium, Conservation \& Legislation. 2012; 5(1): 29-35.

16. Astari IM, Setyawati TR, Yanti AH: The brightness level of comet fish scales fed with seaweed enriched Sargassum sp. and Cucurbita moschata pumpkin.
Jurnal Akuakultur Indonesia. 2016; 15(1): 80-88. [Indonesian]

17. Solihah R, Buwono ID, Herawati T: The effect of the addition of pumpkin flour and shrimp head flour to the improvement in the color quality of goldfish (Carassius auratus). Jurnal Perikanan Kelautan. 2015; 6(2): 107115. [Indonesian]

18. Mirzaee S, Shabani A, Rezaee S, et al. : The effect of synthetic and natural pigments on the color of the guppy fish Poecilia reticulata. Global veterania. 2012; 9(2): 171-174.

19. Yedier S, Gumus E, Livengood EJ, et al. : The relationship between carotenoid type and skin color in the ornamental red zebra cichlid (Maylandia estherae). Bioflux ACCL. 2014; 3(7): 207-216.

20. Kuncoro EB: The success of freshwater ornamental fish farming. C.V Andi Offset. Yogyakarta. 436p. 2011. [Indonesian] 